\title{
TRANSGLUTAMINASE ACTIVITY IN EQUINE STRONGYLES AND ITS POTENTIAL ROLE IN GROWTH AND DEVELOPMENT
}

\author{
RAO U.R.**, CHAPMAN M.R. ${ }^{*}$, SINGH R.N.***, MEHTA K..** \& KLEI T.R.,***
}

\section{Summary :}

Transglutaminases (E.C. 2.3.3.13) are a family of $\mathrm{Ca}^{2+}$-dependent enzymes that stabilize protein structure by catalyzing the formation of isopeptide bonds. A novel form of transglutaminase has been identified and characterized that seem to play an important role in growth, development, and molting in adult and larval stages of filarial nematodes. The aim of this study was to identify the ubiquitous nature of this enzyme in other nematodes and to measure its significance to larval growth, molting, and development. For this purpose, equine Strongylus spp. were used Activity of this enzyme was identified in extracts of larvae and adults of Strongylus vulgaris, S. edentatus, Parascaris equorum and Cylicocyclus insigne. The significance of transglutaminase in the early growth and development of Strongylus vulgaris, S. edentatus and $S$. equinus was tested by adding specific inhibitors, monodansylcadaverine (MDC) or cystamine (CS), to in vitro cultures of third (L3) and fourth stage larvae (L4). The viability, molting and growth of these nematode species were affected by both inhibitors. Cystamine promoted abnormal development of Strongylus edentatus $L 3$, resulting in an aberrant expansion of the anterior end. Addition of these inhibitors to cultures of $L 4$ also reduced growth of the three species. The results indicated that transglutaminase is present in a wide array of nematode parasites and may be important in growth and development of their larval stages

KEY WORDS : equine, strongyles, L3, L4, transglutaminase, growth, molting, inhibitors, monodansylcadaverine (MDC), cystamine (CS).
Résumé : ACTIVITÉ ET RÔLE POTENTIEL DE LA TRANSGLUTAMINASE DANS LA CROISSANCE ET LE DÉVELOPPEMENT DES STRONGYLES ÉQUINS Les transglutaminases (E.C.2.3.3.13) sont une famille d'enzymes $\mathrm{Ca}^{2+}$-dépendantes qui stabilisent la structure protéique en catalysant la formation de ponts isopeptidiques. Une forme nouvelle de transglutaminase a été identifiée et caractérisée; elle semble jover un rôle important dans la croissance, le développement et la mue des stades adultes et larvaires des filaires. L'objectif de cette étude était d'identifier la nature ubiquitaire de cette enzyme chez d'autres nématodes et d'en mesurer l'impact sur la croissance, la mue et le développement larvaires.

Dans ce but, des espèces de Strongylus équines ont été utilisées L'activité enzymatique a été identifiée à partir d'extraits de larves et d'adultes de Strongylus vulgaris, S. edentatus, Parascais equorum et Cylicocyclus insigne. L'impact de la transglutaminase dans la croissance précoce et le développement de Strongylus vulgaris, $\mathrm{S}$. edentatus et $\mathrm{S}$. equinus a été testé par l'addition d'inhibiteurs spécifiques, monodansylcadavérine (MDC) ou cystamine (CS) aux cultures in vitro de larves de troisième (L3) et de quatrième stade (L4). La viabilité, la mue et la croissance de ces espèces de nématodes ont été affectées par les deux inhibiteurs. La cystamine a entraîné un développement anormal des 13 de Strongylus edentatus, se traduisant par une expansion aberrante de l'extrémité antérieure. L'addition de ces inhibiteurs aux cultures de $L 4$ a réduit la croissance des trois espèces. Ces résultats indiquent que la transglutaminase est présente dans toute une collection de nématodes et peut être importante pour la croissance et le développement de leurs stades larvaires.

MOTS CLÉS : équin, strongyles, L3, L4, transglutaminase, croissance, mue, inhibiteur, monodansylcadavérine (MDC), cystamine (CS)

is interesting that the external cortical layer and the epicuticle are highly insoluble proteins covalently crosslinked by nonreducible bonds (Fetterer, 1989; Cox, 1992; Maizels et al., 1993). During the development of cuticulin, such cross linking has been shown previously. Dityrosine and isotrityrosine in cross linking of cuticular proteins of nematodes has been extensively studied, yet the mechanism of synthesis of these crosslinks is unknown (Fujimoto et al., 1981; Fetterer \& Rhoads, 1990; Fetterer \& Hill, 1993; Fetterer et al., 1993). In addition, activity of phenol oxidase in protein cross linking and egg shell development of Trichuris has been suggested (Fetterer \& Hill, 1993). Filarial nematode cuticle development and sheath formation have been attributed to crosslinking of amino acids, resulting in a highly insoluble fraction of the somatic proteins (Selkirk et al., 1989;

* Department of Veterinary Science,

** Department of Microbiology and Parasitology, School of Veterinary Medicine, Louisiana State University, Baton Rouge, Louisiana, *** Department of Bioimmunotherapy, The University of Texas M.D. Anderson Cancer Center, Houston, Texas.

Correspondence: U.R. Rao. Ph.D., Washington University School of Medicine, Infectious Diseases Division, Barnes Jewish Hospital (N), 216 South Kings Highway, St.Louis, MO 63110.

Tel.: 3144547483 - Fax: 3144545293 .

Email: RRAO@imgate.wustl.edu 
Hirzmann Jorg et al., 1995; Zahner et al., 1995). Similarly, the highly insoluble complexes of larval or adult strongyle extracts reveal the presence of similar cross linking of isopeptide bonds. Recently, transglutaminase (TGase), a new type of protein cross linking enzyme, has been observed in lymphatic filarial nematodes (Mehta et al., 1990, 1992; Rao et al., 1991), as well as Dirofilaria immitis (Singh et al., 1995 ) and Onchocerca volvulus (Lustigman et al., 1995), and possibly plays a role in molting, growth, and development of these parasites. Moreover, TGase was also involved in covalent incorporation of host proteins into developing stages of Brugia malayi (Mehta et al., 1996).

Equine strongyles are pathogenic gastrointestinal nematodes of horses and have been associated with a wide range of clinical syndromes (DiPietro et al., 1990; Klei, 1992). In immune and non-immune equines, the infection is always transmitted by ingested third stage larvae (L3). The three Strongylus species that we have used in this study have complex life cycles and each of them are different. These larvae exsheath in the intestine and migrate through the mucosa. Exsheathed L3 of S.edentatus migrate through the venous system to the liver during the first $40 \mathrm{hrs}$ of the infection and eventually to the colon (McCraw \& Slocombe, 1974). L3 of S.equinus migrate into the liver via the peritoneal cavity, and then to the colon via pancreas (McCraw \& Slocombe, 1985). However, molting, growth, and development through L4 and L5 stages of S. vulgaris occur in the arterioles (Enigk, 1970). Pathological symptoms are usually associated with these early developmental stages during their tissue migration (Drudge et al., 1966, 1989; Enigk, 1970; McCraw \& Slocombe, 1985). Although the periodic treatment by anhelminthics, e.g., pyrantel pamoate, benzimidazoles and ivermectin, is highly efficacious against migrating strongyle larvae; the latter two are active against larvae and adults. Therefore, a specific and targeted approach in designing new compounds has always been a better choice in new drug development. This approach is worth pursuing as there has been emerging evidence of drug resistance in strongyles (Slocombe, 1992). The objective of the present study was to investigate the presence of transglutaminase activity in different species of strongyle nematodes and to measure its biological activity in molting, growth, and development of L3 and L4 stage larvae in vitro by using two known transglutaminase inhibitors, monodansylcadaverine and cystamine.

\section{MATERIALS AND METHODS}

\section{PARASITES}

trongylus vulgaris L3 and S. edentatus L3 were obtained from ponies with surgical implantation of monospecific infections (McClure et al., 1994).
Strongylus equinus L3 were recovered from naturally infected ponies. Adult male and female worms of these species recovered from intestines were washed repeatedly in phosphate-buffered saline (PBS). Developing larvae and adults of Parascaris equorum and Cylicocylus insigne were also collected from naturally infected ponies at necropsies and washed thoroughly in PBS. All these adult worms or L3 stages were stored in PBS at $-70 \mathrm{C}$ until use.

L3 recovery from fecal collection, culture, purification and further exsheathing were essentially carried out as described by Farrar \& Klei., (1985) and Klei et al., (1982). Larvae were cultured using media and methods as described by Chapman et al., (1994) to obtain L4 stages. For soluble parasite extract preparations, L3 (ensheathed), L3 (exsheathed), L4, and male and female $S$. edentatus were homogenized separately in Tris-HCl buffer $(20 \mathrm{mM})$, pH 8.5, containing a cocktail of $2 \mathrm{mM} \mathrm{1,4-dithiothreitol,} 1 \mathrm{mM}$ ethylenediamine tetra acetic acid (EDTA), $1 \mathrm{mM}$ phenylmethylsulfonyl fluoride, $0.1 \mathrm{mM}$ N-tosyl-L-lysine choloromethane, $0.1 \mathrm{mM}$ N-tosyl-L-lysine chloromethane, and $0.1 \mathrm{mM} \mathrm{N}$-tosylL-phenylalanine chloromethane for $20 \mathrm{~min}$ on ice. The homogenized extract was then sonicated continuously for three cycles of one min, with five min stop-cycle, using a W-225 ultrasonic processor on ice. The crude extract was mixed with $0.1 \%$ Triton $\mathrm{x}-100$ and resonicated for five min. The suspension was centrifuged at 15,000 $\mathrm{g}$ for $20 \mathrm{~min}$; supernatant was filtered through a sterile millipore filter $(0.2 \mu \mathrm{m})$. Protein concentrations of soluble extracts were estimated with a commercial kit (Pierce Chemical Co., Rockford, Illinois) and stored at $-70 \mathrm{C}$ until use.

\section{INHIBITORS}

Two TGase inhibitors were used, e.g., monodansylcadaverine (MDC), a competitive substrate inhibitor; and cystamine (CS), an active-site inhibitor (Sigma chemical company, St. Louis, Missouri). Millimolar concentrations of these inhibitors were prepared before each experiment and the $\mathrm{pH}$ of the culture solution was adjusted if necessary after the addition of the inhibitor such that it was maintained at 7.2-7.5.

\section{IN VTTRO CULTURE OF L3 AND L4}

Culture of equine strongyles from third to the fourth stage larvae using standard medium and gas phase $\left(10 \% \mathrm{CO}_{2}, 5 \% \mathrm{O}_{2}\right.$ and $85 \% \mathrm{~N}_{2}$ ) always yielded 44 $95 \%$ molting depending on the species (Chapman et al., 1994). Under these conditions, L3 were cultured in vitro for 6-10 days depending on species. TGase inhibitors were added to these cultures at day 0,6 , or 11 at increasing concentrations from $0.05,0.1,0.3$, 
0.5 and $1 \mathrm{mM}$. The number of molting larvae was determined on day 4 and 6 for $S$. vulgaris, and day 6 and 10 for S. edentatus and S. equinus. Larval viability was measured by microscopic observation of motility and integrity. Duplicate samples of the cultures were obtained at each time to measure the growth and development. For this purpose, larval stages were transferred to clean glass slides. The width and length of these stages were scored morphometrically using a compound microscope fixed with a ocular micrometer. When larval movement was sufficient to interfere with measurements, a drop of $2 \%$ NaAzide was added to the side of the coverslip to paralyze the larvae. Larval samples were prepared in a similar manner to determine the abnormal changes during larval development. Experiments were repeated and the results on viability, molting, and growth for each inhibitor concentration were shown as an increase or decrease in percent when compared with those of control larvae cultured in parallel without inhibitors.

\section{TGASE ACTIVITY}

\section{IN SOLUBLE EXTRACT PREPARATIONS}

Enzyme activity in soluble extracts of L3, L4, and males and females was determined according to the previously described method (Singh \& Mehta, 1994). In brief, microtiter plates were coated with $0.2 \%$ dimethyl casein at $37 \mathrm{C}$ for $1 \mathrm{hr}$. The wells were blocked with $0.5 \%$ nonfat dry milk; $200 \mu \mathrm{l}$ of reaction mixture containing $100 \mathrm{mM}$ Tris- $\mathrm{Hcl}(\mathrm{pH} \mathrm{8.5)}$, $10 \mathrm{mM} \mathrm{CaCl} 2$ or ethylenediaminetetraacetic acid (EDTA), $10 \mathrm{mM}$ dithiotheritol (DTT), $1 \mathrm{mM}$ BPA (5[biotinamido]pentylamine) and the soluble extract was added to each well and incubated at $37 \mathrm{C}$ for 1 hr. Enzyme catalyzed conjugation of BPA into dimethyl casein was detected by streptavidin-alkaline phosphatase and p-nitrophenyl phosphate as a substrate; $2 \mathrm{mM}$ of sodium bicarbonate was used as stopping solution of the enzyme reaction, and absorbance was determined at $405 \mathrm{~nm}$ using a Vmax kinetic microplate reader (Molecular Devices, Palo Alto, California). Known concentrations of guinea pig liver transglutaminase (GPTGase) was used in each plate to generate a standard curve under similar conditions.

\section{STATISTICAL ANALYSIS}

Significance of differences in larval molting and growth was tested by using 1-way analysis-of- variance; all pairwise multiple comparisons were made using the Student-Newman-Keuls method, or Dunn's method, or both. The differences between the groups were considered significant when the $P$ values were $<0.05$.

\section{RESULTS}

\section{TGASE ACTIVITY IN SOLUBLE EXTRACTS OF LIFE CYCLE STAGES OF STRONGYLUS EDENTATUS, PARASCARIS EQUORUM AND CYLICOCYCLUS INSIGNE}

Trongylus edentatus, due to its abundance, was used as the base-line species to measure the acti$\checkmark$ vity of TGase in vitro by employing a highly sensitive microwell plate assay that utilizes a chemical reaction between an amine acceptor (N-N-dimethylcasein) and an amine donor substrate BPA (Singh \& Mehta, 1994). High levels of TGase were detected by this method, e.g., $160 \mathrm{ng} / \mathrm{mg} /$ protein (in L3 at day 3 of culture ) and $100 \mathrm{ng} / \mathrm{mg} /$ protein (in L4 at 22 days of culture). The levels were insignificant in larvae collected from cultures where molting did not occur. TGase was 262 and $205 \mathrm{ng} / \mathrm{mg}$ protein in developing male and female worms at the L5 stages, respectively. Their concentrations were higher in mature adult males (214 $\mathrm{ng} / \mathrm{mg} /$ protein) than mature females (158 ng/mg/protein). It is interesting that the enzyme activity is $\mathrm{Ca}^{+2}$-dependent in this assay, an important feature of TGase catalyzed reactions, and could be inhibited by chelating agent EGTA (data not shown). The enzyme activity was also observed in soluble extracts of young adults of Parascaris equorum (130.5 ng/mg/protein) and in developing $\mathrm{L} 3$ ( $87 \mathrm{ng} / \mathrm{mg} /$ protein) and adults (360 ng/mg/protein) of Cylicocyclus insigne.

\section{EFFECT OF TGASE INHIBITORS ON L3 VIABILITY, MOLTING AND GROWTH}

In an initial experiment to determine whether TGase catalyzed reactions have any role in the viability of Strongylus spp., the effect of two known TGase inhibitors was tested on the viability of S. edentatus, S. vulgaris, and S. equinus L3. Cystamine, an active site inhibitor, or MDC, a potent competitive substrate inhibitor that can be assimilated and is effective in blocking the endogenous TGase catalyzed protein crosslinking, were added to the L3 cultures at $\mathrm{mM}$ concentrations. The viability of larvae in these cultures was determined microscopically during the culture period. Cystamine at $0.5 \mathrm{mM}$ showed no effect on viability of any of the three species (Figs. 1A-C). However, at an equimolar concentration, MDC induced significant reduction in larval viability of $S$. edentatus and S. equinus, but not S. vulgaris. CS did not affect the larval viability at $1 \mathrm{mM}$, whereas, in contrast MDC induced a marked inhibitory effect on larval viability of all three strongyle species (data not shown). These results suggest that the uptake or absorption rate of these inhibitors or their mode of action may not be equal within these species, thus producing the differences seen in viability at posttreatment times. 

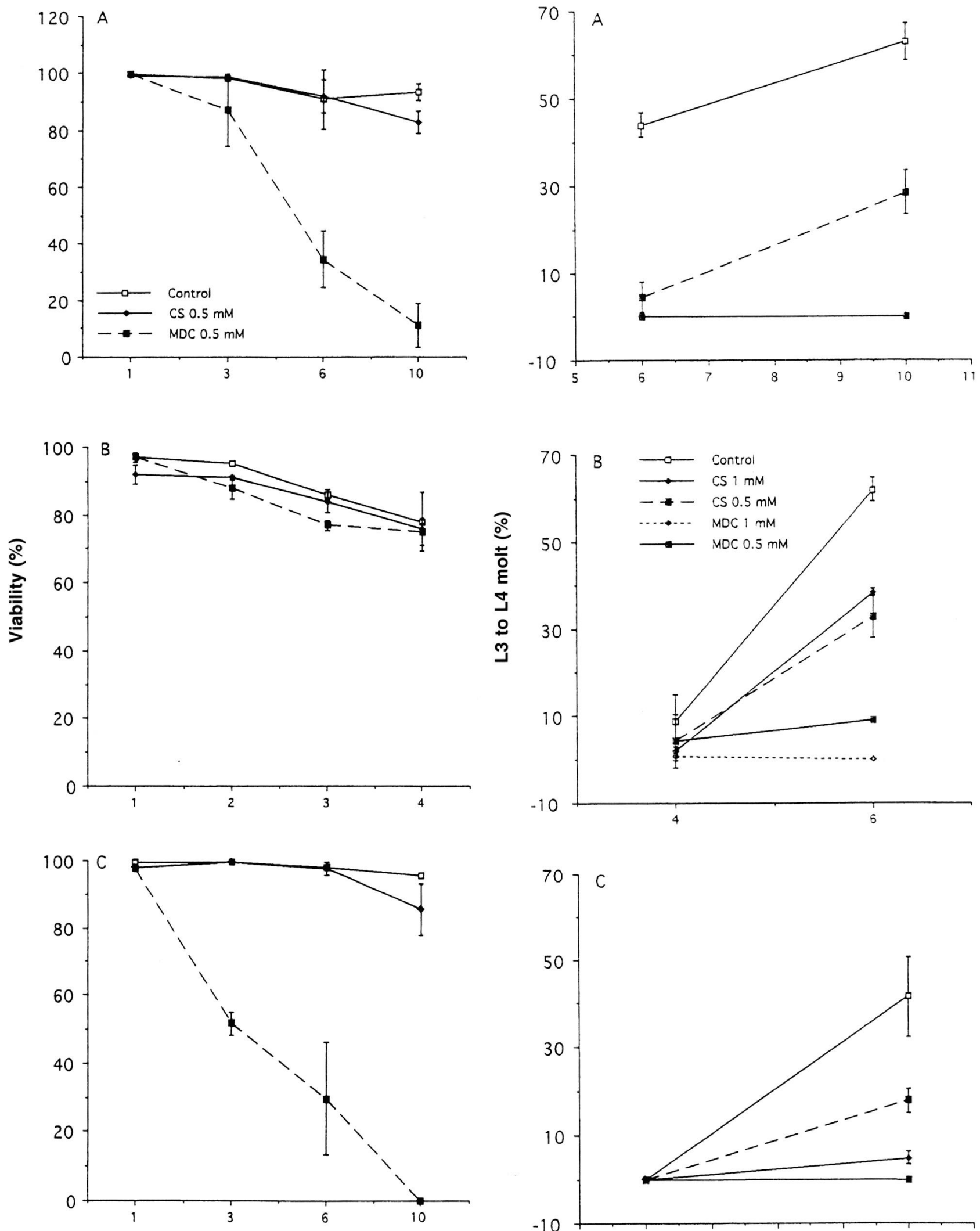

Time in culture (Days)

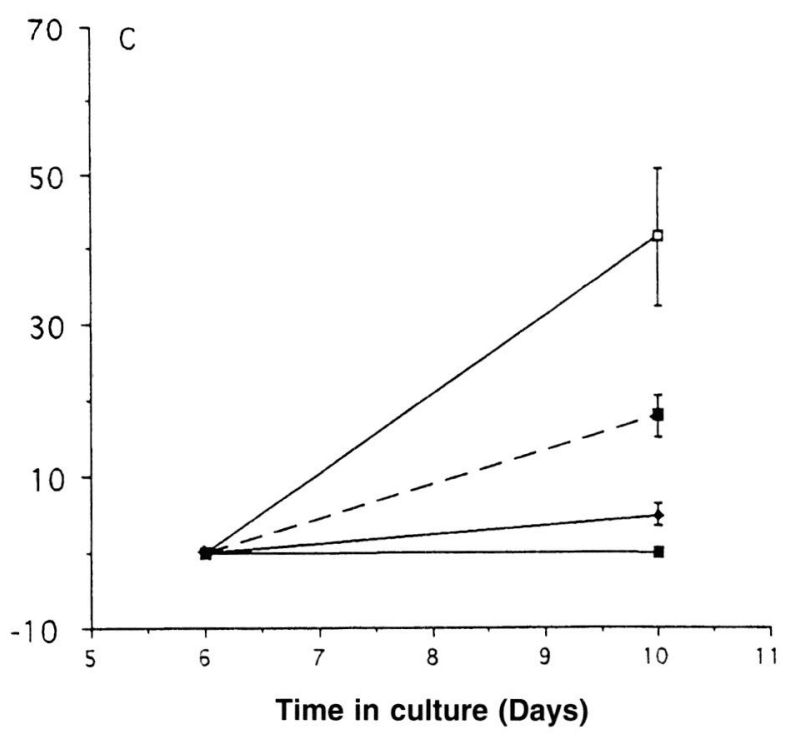

Fig. 1. - In vitro effect of MDC and CS on Strongylus edentatus (A), S. vulgaris (B) and S. equinus (C) L3 viability. Results are expressed as means \pm SE of duplicate samples.

Fig. 2. - In vitro effect of MDC and CS on Strongylus edentatus (A), S. vulgaris (B) and S. equinus (C) L3 molting. Results represent means $\pm \mathrm{SE}$ of duplicate samples. 
The effect of these two inhibitors on molting of $\mathrm{L} 3$ to $\mathrm{L} 4$ was also tested. Culture periods selected for molting and viability measurements of each species were based on previous observations (Chapman et al., 1994). To measure the effect of inhibitors, larval cultures were supplemented with two concentrations of CS or MDC and incubated as previously described. Cystamine at $1 \mathrm{mM}$ and MDC at both the concentrations tested, greatly inhibited $S$. edentatus $\mathrm{L} 3$ molting to L4 when compared with controls (Fig. 2A). Cystamine at $0.5 \mathrm{mM}$ was marginally effective compared to that at $1 \mathrm{mM}$. Molting was completely inhibited by day 10 in cultures containing CS at $1 \mathrm{mM}$; and MDC at 0.5 or $1 \mathrm{mM}$. Similarly, Figure 2B shows the effect of both MDC and CS on S. vulgaris L3 molting to L4. Both the inhibitors reduced the molting by day 6 . However, the effect of MDC was much greater than CS at these concentrations. Whereas MDC at $0.5 \mathrm{mM}$ and $1 \mathrm{mM}$ caused $80-100 \%$ inhibition in S. vulgaris molting to L4, CS reduced molting by 37 and $46 \%$ on day 6; CS at these concentrations appeared to delay rather than inhibit the molting process. Control cultures of $S$. equinus $\mathrm{L} 3$ showed no molting at day 6 and $41 \pm 9 \%$ molting to L4 by day 10 (Fig. 2C). Molting of these larvae was significantly inhibited at day 10 by cystamine at 1 and $0.5 \mathrm{mM}(P<0.05)$. MDC at the same concentrations appeared lethal to these larvae during their culture from day 6 to 10 .

Table I illustrates an average increase in growth measurements of these L3 to L4 cocultured with inhibitors. These values were obtained by comparing measurements at the initiation of culture and at 10 days of culture. The results indicate marked reduction in larval sizes by MDC and CS. Also, an abnormal enlargement of anterior (buccal) region was noticed in S. edentatus L3 that did not molt to L4 stage larvae (Fig. 3).

\section{EFFECT OF TGASE INHIBITORS ON L4 VIABILITY AND GROWTH}

Cystamine and MDC were added at appropriate concentrations on day 6 to S. vulgaris, on day 11 to

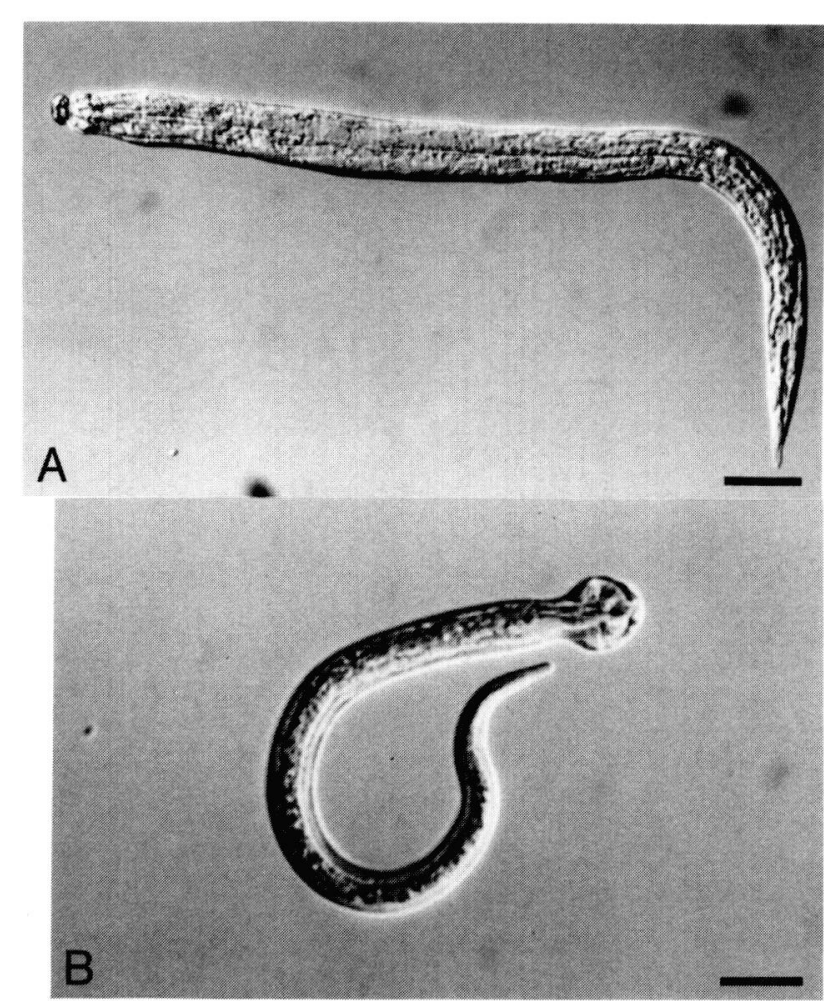

Fig. 3. - Effect of CS on Strongylus edentatus (L3). Control L3 cultured under normal conditions as described in methods section (A); L3 cultured with $0.5 \mathrm{mM}$ CS at day 10 showing an abnormal anterior end (B). Scale bar $=10 \mu \mathrm{m}$.

S. edentatus, and on day 6 to S. equinus L4 cultures. Viability and growth were measured on days 8,10 , and 13 (Fig. 4A) for S. vulgaris and S. equinus, and on days 12 and 18 (Fig. 4B) for $S$. edentatus. These results indicate that CS had less effect on viability of these parasites at all the concentrations tested. However, MDC at high concentrations showed an inhibitory effect on viability of L4. It is interesting that both the inhibitors significantly reduced the L 4 growth as determined by length and width measurements (Table II).

\begin{tabular}{|c|c|c|c|c|c|c|c|}
\hline \multirow[b]{2}{*}{ Inhibitor } & \multirow[b]{2}{*}{$\begin{array}{l}\text { Conc } \\
(\mathrm{mM})\end{array}$} & \multicolumn{3}{|c|}{ S. edentatus } & \multicolumn{3}{|c|}{ S. equinus } \\
\hline & & Width $^{1}$ & length ${ }^{2}$ & $\begin{array}{l}\% \text { inhibition } \\
\text { in length }\end{array}$ & Width $^{1}$ & Length $^{2}$ & $\begin{array}{l}\% \text { inhibition } \\
\text { in length }\end{array}$ \\
\hline \multirow[t]{2}{*}{ Cystamine (CS) } & 0.5 & 154.7 & 0.0 & 100 & 97.1 & 0 & 100 \\
\hline & 1.0 & 88.7 & 13.4 & 56 & 42.9 & 0 & 100 \\
\hline \multirow[t]{2}{*}{ Monodansylcadaverine (MDC) } & 0.5 & 66.7 & 24.9 & 19 & 14.3 & 2.5 & 26 \\
\hline & 1.0 & 56.7 & 23.4 & 24 & 0 & 0 & 100 \\
\hline None & - & 193.3 & 30.6 & - & 117.1 & 3.4 & - \\
\hline
\end{tabular}

* Growth was determined by morphometric measurements on the width ( ${ }^{1}$ ) and length ( ${ }^{2}$ ) of larvae from day 6-10.

$3: \%$ inhibition $=\%$ reduction of average length of larvae cultured with inhibitor as compared to average larval length in medium alone controls.

Table I. - Increase (\%) in growth* of Strongylus edentatus and S. equinus- L3 to L4 in cultures containing transglutaminase inhibitors. 

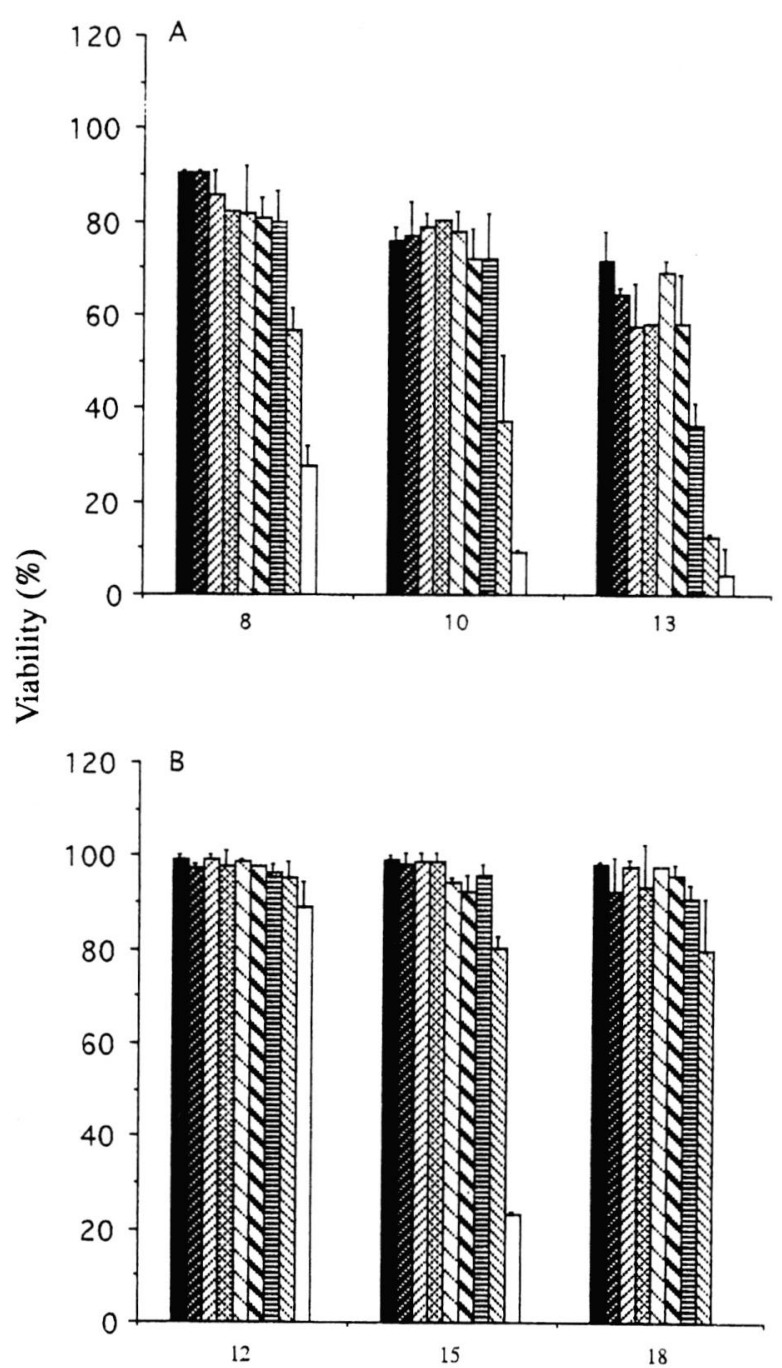

Time in culture (Days)

Fig. 4. - In vitro effect of MDC and CS on viability of Strongylus vulgaris (A) and S. edentatus (B) L4. Results are expressed as means \pm SE of duplicate samples. growth and development, and microfilarial production was implicated (Rao et al., 1991). Transglutaminase activity was also shown to play a role during molting of L3 to L4 stages of O. volvulus (Lustigman, 1993). Biochemical evidence suggests that the presence of TGase catalyzed cross linking of $\gamma$-(glutamyl)isopeptides in the maturation of sheath and cuticle of filarial nematodes (Mehta et al., 1992; Tarcsa et al., 1992; Zahner et al., 1995; Conraths et al., 1997). It is interesting that the mammalian enzyme is quite distinct from the parasite enzyme in substrate specificity, enzyme activity and molecular mass (Mehta et al., 1992; Singh et al., 1995; Lustigman et al., 1995).

In the present study we have shown the ubiquitous nature of this enzyme by identifying its activity in different stages of strongyle parasites and in adult worms of two other gastrointestinal nematodes of equids. The cytosol preparations from crude extracts of $B$. malayi and D. immitis and partially purified enzyme preparations of parasite-TGase and their specific inhibition of enzyme activity by using various inhibitors clearly suggest the biological activity of this enzyme in cross linking of parasite proteins (Singh \& Mehta, 1994; Lustigman et al., 1995; Singh et al., 1995). However, effect of inhibitors on the enzyme activity of purified protein of strongyles is unknown. Recently, the TGase enzyme from dog filarial nematode was cloned and showed no sequence homology to any known TGases (Chandrashekar et al., 1998). Whether TGase from strongyles also represents a novel protein remains to be determined. Nevertheless, these results suggest that TGase of nematodes could serve as an effective target enzyme to develop effective broad spectrum chemotherapeutic agents against a wide range of nematode parasites.

We used two specific inhibitors to show their inhibition of biological activity of TGase in viability, molting, and growth of L3 to L4 of Strongylus species in vitro. For this purpose, CS that inactivates the enzyme activity by binding to the active site and MDC, a competitive amine substrate inhibitor that inhibits specifically the endogenous protein crosslinking by TGase (Lorand et al., 1979; Folk, 1980; Castelhano et al., 1990; Auger et al., 1993) were used at millimolar concentration. The results indicate that neither inhibitor affects larval viability of S. vulgaris and S. equinus. Strongylus edentatus viability was affected when incubated at high concentrations of MDC. Similarly, the MDC effect on molting of L3 to L4 is greater when compared with CS and the latter appears to delay the molting process of $S$. vulgaris L3. Moreover, the effect on viability and molting within the species was varied. For example, $S$. edentatus and S. equinus were more sensitive to CS and MDC effects than S. vulgaris. Both the inhibitors seemed lethal to the S. equinus and S. edentatus L3 


\begin{tabular}{|c|c|c|c|c|c|c|c|c|c|c|}
\hline \multirow[b]{2}{*}{ Inhibitor } & \multirow[b]{2}{*}{$\begin{array}{l}\text { Conc } \\
(\mathbf{m M})\end{array}$} & \multicolumn{3}{|c|}{ S. edentatus } & \multicolumn{3}{|c|}{ S. vulgaris } & \multicolumn{3}{|c|}{ S. equinus } \\
\hline & & Width $^{1}$ & Length ${ }^{2}$ & $\begin{array}{c}\text { Inhibition } \\
\text { in length } \\
(\%)^{3}\end{array}$ & Width $^{1}$ & Length $^{2}$ & $\begin{array}{l}\text { Inhibition } \\
\text { in length } \\
(\%)^{3}\end{array}$ & Width $^{1}$ & Length $^{2}$ & $\begin{array}{c}\text { Inhibition } \\
\text { in length } \\
(\%)^{3}\end{array}$ \\
\hline \multirow[t]{4}{*}{ Cystamine (CS) } & 0.05 & 34 & 25 & 42 & 15.7 & 29 & 31 & 63 & 24 & 52 \\
\hline & 0.1 & 27 & 26 & 39 & 15.7 & 20 & 52 & 50 & 14 & 72 \\
\hline & 0.3 & 16 & 35 & 18 & 15.7 & 18 & 57 & 44 & 0 & 100 \\
\hline & 0.05 & 20 & 32 & 25 & 15.7 & 25 & 40 & 0 & 0 & 100 \\
\hline \multirow{4}{*}{$\begin{array}{l}\text { Monodansylcadaverine } \\
\text { (MDC) }\end{array}$} & 0.5 & 20 & 26 & 39 & 15.7 & 13 & 69 & 25 & 0 & 100 \\
\hline & 0.1 & 14 & 34 & 21 & 6.2 & 25 & 40 & 0 & 0 & 100 \\
\hline & 0.3 & 14 & 8 & 81 & 15.7 & 7 & 83 & 0 & 0 & 100 \\
\hline & 0.5 & $\mathrm{D}$ & $\mathrm{D}$ & - & $\mathrm{D}$ & $\mathrm{D}$ & - & 0 & 0 & 100 \\
\hline None & - & 27 & 43 & - & 25.3 & 42 & - & 50 & 50 & \\
\hline
\end{tabular}

* Growth measurements were made morphometrically on the width $\left(^{1}\right)$ and length ${ }^{(2)}$ of larvae.

${ }^{a}$ : measurements were made from day $10-19{ }^{b}$ : from day $6-15$; $^{\text {c: }}$ from day $14-20$.

D: Dead.

${ }^{3}: \%$ inhibition $=\%$ reduction of average length of larvae cultured with inhibitor as compared to average larval length in medium alone controls.

Table II. - Growth* measurements of Strongylus vulgaris ${ }^{\mathrm{a}}$, S. edentatus ${ }^{\mathrm{b}}$ and S. equinus ${ }^{\mathrm{c}}$ L4's in cultures containing transglutaminase inhibitors.

during molting phase to L4 when used at higher concentrations. The inhibition of molting indicates that TGase catalyzed crosslinking may be involved in the formation of a new cuticle and any failure in this biochemical process may affect the molting process. These results are in agreement with previous observations of TGase inhibition leads to the inhibition of O. volvulus L3 molting (Lustigman et al., 1995). However, CS was less effective in inhibiting $S$. vulgaris larval molting and this could be due to the species variation in type and nature of cuticular makeup and transcuticular absorption. Apparently, strongyle larvae are more fastidious than filarial nematodes as they can withstand high temperatures and enzymes when compared with their comparable stages of filarial nematodes. For example, strongyle larvae are resistant to a wide range of adverse conditions for prolonged periods (Ogbourne \& Duncan, 1985). Therefore, the concentration of inhibitors needed to test the viability and molting of Strongylus spp. was greater than what has been used for such studies with Brugia or Onchocerca.

Evidence from ultrastructural studies suggests that in O. volvulus, these two inhibitors did not affect the new L4 cuticle formation during L3 growth to L4, but the cuticle was inseparable at some junctions on the surface from the old cuticle during ecdysis (Lustigman et al., 1995). These authors also have noticed the TGase catalyzed cross linked protein, $\varepsilon$ - $(\boldsymbol{\gamma}$-glutamine)lysine in developing L3 by immunoprecipitation studies strongly suggesting the biological activity of this enzyme in molting process. In this study under normal conditions, shedding of the cuticle began at the anterior end of emerging L4's from the old cuticle and leaving behind these cuticle casts in culture medium. However, strongyle larvae particularly $S$. edentatus L3's incubated with the active site inhibitor CS failed to molt to L4's showed an abnormal bulging of the anterior end suggesting that at optimal concentrations, TGase inhibitors may inhibit the release of larval cuticle. Therefore, the developing larvae begin to enlarge within the old cuticle, by that causing an abnormal cephalic bulge. In contrast, the other two species failed to show such an abnormal development, which could be explained as species variation in cuticular turnover and initiation signals for ecdysis. Effect on L4 viability with MDC and growth with both the inhibitors strongly supports the notion that TGase is involved in growth and development of these nematodes. N-bezyloxycarbonyl-D,L-b-(3-bromo-4,5-dihydroisoxazol-5-yl)-alanine benzylamide (Syntex Inc., Palo Alto, CA), another TGase inhibitor that like CS binds to the active site of TGase (Auger et al., 1993; Castelhano et. al., 1990), also inhibited O. volvulus larval molting (Lustigman et al., 1995) and Nippostrongylus braziliensis L4 viability and molting to adult (Castelhano et al. 1990). Although these studies have identified the presence of TGase enzyme in a wide range of nematode species, additional studies are needed to determine the regulatory activity of TGase in molting process and worm development in vivo (Geary et al., 1995). Secondly, what triggers the enzyme activity in protein cross linking during the growth of these parasites is unknown.

In summary, these results strongly support the presence of TGase in parasitic nematodes and its involvement in molting and growth of larval stages. TGase thus 
represents an important regulatory enzyme that may be targeted for antiparasitic studies by the use of highly potent parasite-specific enzyme inhibitors.

\section{ACKNOWLEDGEMENTS}

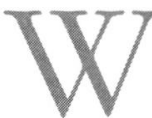

Te are thankful to the support of Onchocerciasis Control Programme in West Africa, United Nations Development Program/World Bank/World Health Organization Special Program for Research and Training in Tropical Diseases, Macrofil Chemotherapy Project (KM).

\section{REFERENCES}

Auger M., McDermott A.E., Robinson V., Castelhano A.L., Billedeau R.J., Pliura D.H., Krantz A. \& Griffin R.G. Solidstate 13 C NMR study of a transglutaminase inhibitor adduct. Biochemistry, 1993, 32, 3930-3934

Castelhano A.L., Pliura D.H. \& Venuti M.C. Transglutaminase inhibitors. 1990, U.S. Patent 4, 970, 297.

Chandrashekar R., Tsuji N., Morales T., Ozols V. \& Mehta K. An ERp60 like protein from the filarial parasite Dirofilaria immitis has both transglutaminase and protein disulfide isomerase activity. Proceedings of the National Academy of Sciences of the United States of America, 1998, 95, 531536.

Chapman M.R., Hutchinson G.W., Cenac M.J. \& Klei T.R. In vitro culture of equine strongylidae to the fourth larval stage in a cell-free medium. Journal of Parasitology, 1994, 90, 225-231.

Conraths F.J., Hirzmann J., Hobom H. \& Zahner H. Expression of the microfilarial sheath protein $2(\operatorname{shp} 2)$ of the filarial parasites Litomosoides sigmodontis and Brugia malayi. Experimental Parasitology, 1997, 85, 241-248.

Cox G.N. Molecular and biochemical aspects of nematode collagens. Journal of Parasitology, 1992, 78, 1-15.

Cox G.N., Kusch M. \& Edgar R.S. Cuticle of Caenorhabditis elegans: its isolation and partial characterization. Journal of Cell Biology, 1981, 90, 7-17.

DiPietro J.A., Klei T.R. \& French D.D. Contemporary topics in equine parasitology. Compendium on Continuing Education for the Practicing Veterinarian, 1990, 12, 713- 721.

Drudge J.H., Lyons E.T. \& Tolliver S.C. Strongyles-An update. Equine practice, 1989, 11, 43-49.

Drudge J.H., Lyons E.T. \& Szanto J. Pathogenesis of migrating stages of helminths with special reference to Strongylus vulgaris. In: Biology of parasites with emphasis on veterinary parasites. Soulsby E.J.L.(ed). Academic Press, New York, New York, 1966, 199-214.

ENIGK K. The development of the three species of Strongylus of the horse during the prepatent period. In: Equine infectious diseases (Proceedings of the second International Conference of Equine Infectious Diseases, Paris, 1969), Bryans J.T., Gerber H. \& Krager S (eds.) Basel, Switzerland, 1970, 259-268.
FARRAR R.G. \& KLEI T.R. In vitro development of Strongylus edentatus to the fourth larval stage with notes on Strongylus vulgaris and Strongylus equinus. Journal of Parasitology, 1985, 71, 489-499.

FETtERER R.H. The cuticular proteins from free-living and parasitic stages of Haemonchus contortus. Isolation and partial characterization. Comparative Biochemistry and Physiology, 1989, 94, 383-388.

FetTerer R.H. \& Hill D.E. The occurance of phenol oxidase activity in female Trichuris suis. Journal of Parasitology, 1993, 79, 155-159.

Fetterer R.H. \& RhOAds M.L. Tyrosine-derived cross-linking amino acids in the sheath of Haemonchus contortus infective larvae. Journal of Parasitology, 1990, 76, 619-624.

Fetterer R.H., Rhoads M.L. \& Urban J.F. Synthesis of tyrosine-derived cross-links in Ascaris suum cuticular proteins. Journal of Parasitology, 1993, 79, 160-166.

Folk J.E. Transglutaminases. Annual Review of Biochemistry, 1980, 49, 517-531.

Fujimoto D. \& Kanaya S. Cuticulin: a noncollagen structural protein from Ascaris cuticle. Archieves of Biochemical Biophysics, 1973, 157, 1-6.

Fujimoto D., Hortiuchi K. \& Hirama M. Isotrityrosine, a new crosslinking aminoacid isolated from Ascaris cuticle collagen. Biochemical Biophysical Communications, 1981, 99 , 637-643.

Geary T.G., Blair K.L., Ho N.F.H., Sims S.M. \& Thompson D.P. Biological functions of nematode surfaces. In: Molecular Approaches to Parasitology (Boothroyd J.C. \& Komuniecki R. (eds), Wiley-Liss, Inc., 1995, 57-76.

Hirzmann J., Schnaufer A., Hintz M., Conraths F., Stirm S., Zahner H. \& Hobom G. Brugia spp. and Litomosoides carinit: Identification of a covalently cross-linked microfilarial sheath matrix protein (shp2). Molecular and Biochemical Parasitology, 1995, 70, 95-106.

KLEI T.R. Recent observations on the epidemiology, pathogenesis and immunology of equine helminth infections. In: Equine Infectious Diseases VI. Proceedings of the Sixth international conference. Plowright W, Rossdale P.D. \& Wade J.F. (eds) R \& W Publications, Newmarket, U.K., 1992, 129-138.

Klei T.R., Torbet B.J., Ochoa R. \& Bello T.R. Morphologic and clinicopathologic changes following Strongylus vulgaris infections of immune and nonimmune ponies. American Journal of Veterinary Research, 1982, 43, 1300-1307.

Lorand L., Parameswaran K.N., Stenberg P., Tong Y.S., Velasco P.T., Johnson N.A., Mikiver L. \& Moses P. Specificity of guinea pig liver transglutaminase for amine substrates. Biochemistry, 1979, 18, 1756-1765.

Lustigman S. Molting, enzymes and new targets for chemotherapy of Onchocerca volvulus. Parasitology Today, 1993, 9, 294-297.

lustigman S., Brotman B., Huima T., Castelhano A.L., Singh R.N., Mehta K. \& Prince A.M. Transglutaminase-catalyzed reaction is important for molting of Onchocerca volvulus third-stage larvae. Antimicrobial Agents and Chemotherapy, 1995, 39, 1913-1919. 
Maizels R.M., Blaxter M.L. \& SelkiRK M.E. Forms and functions of nematode surfaces. Experimental Parasitology, 1993, 77, 380-384.

McCraw B.M. \& Slocombe J.O.D. Early development of and pathology associated with Strongylus edentatus. Canadian Journal of Comparative Medicine, 1974, 33, 124-138.

McCraw B.M. \& SLOCOMBE J.O.D. Strongylus equinus: development and pathological effects in the equine host. Canadian Journal of Comparative Medicine, 1985, 49, 372-383.

McClure J.R., Chapman M.R. \& Klei T.R. Production and characterization of monospecific adult worm infections of Strongylus vulgaris and Strongylus edentatus in ponies. Veterinary Parasitology, 1994, 51, 249-254.

Mehta K., Chandrashekar R. \& RaO U.R. Transglutaminasecatalyzed incorporation of host proteins in Brugia malayi microfilariae. Molecular and Biochemical Parasitology, 1996, 76, 105-114.

Mehta K., Rao U.R., Vickery A.C. \& Birkbichler.P.J. Significance of transglutaminase catalyzed reactions in growth and development of filarial parasite, Brugia malayi. Biochemical Biophysical Research Communications, 1990, 173, 1051-1057.

Mehta K., RaO U.R., Vickery A.C. \& Fesus L. Identification of a novel transglutaminase from the filarial parasite Brugia malayi and its role in growth and development. Molecular and Biochemical Parasitology, 1992, 53, 1-16.

Ogbourne C.P. \& Duncan J.L. Strongylus vulgaris in the horse: Its biology and veterinary importance. Miscellaneous publications No. 9. Commonwealth Institute of Parasitology. St. Albans, Herts, U.K., 1985, 68.

Rao U.R., Mehta K., Subrahmanyam D. \& Vickery A.C. Brugia malayi and Acanthocheilonema viteae: antifilarial activity of transglutaminase inhibitors in vitro. Antimicrobial Agents and Chemotherapy, 1991, 35, 2219-2224.

Selkirk M.E., Nielson l., Kelly C., Partono F., Sayers G \& MaIzels R.M. Identification, synthesis and immunogenicity of cuticular collagens from the filarial nematodes Brugia malayi and Brugia pabangi. Molecular and Biochemical Parasitology, 1989, 32, 229-246.

Singh R. N., Chandrashekar R. \& Mehta K. Purification and partial characterization of a transglutaminase from dog filarial parasite, Dirofilaria immitis. International Journal of Biochemistry and Cell Biology, 1995, 27, 1285-1291.

SINGH R.N. \& MEHTA K. Purification and characterization of a novel trans-glutaminase from filarial nematode Brugia malayi. European Journal of Biochemistry, 1994, 225, 625-634.

SLOCOmBE J.O.D. Anthelminthic resistance in strongyles of equids. In: Equine infectious diseases VI. Proceedings of the sixth international conference, Plowright W., Rossdale P.D. \& Wade J.F. (eds). R \& W Publications, Newmarket, U.K., 1992,137-143.

Tarcsa E., Eskerstorfer M., Breitenbach M., Hintz M., Schott H.H., Zahner H.H. \& STRIM S. $\varepsilon$-( $\gamma$-glutamyl)lysine crosslinks in Litomosoides carinii microfilarial sheaths. Parasitology Research, 1992, 78, 623-624.

Zahner H., Новом G. \& Strim S. The microfilarial sheath and its proteins. Parasitology Today, 1995, 11, 116-120.

Reçu le 7 décembre 1998

Accepté le 27 mars 1999 